\title{
COOPERATIVE SELF-HELP HOUSING
}

\author{
Tom L. Davis*
}

Too many people in our country are badly housed. According to the Ig6o census, Io.6 million units of the available 58.3 million housing units were considered substandard. In urban areas there were 4.3 million substandard units; 4.8 million substandard units were in rural nonfarm communities, and on rural farms there were x.5 million such units. ${ }^{1}$ Except where aided by grants or subsidies, the poor of the nation are found in substandard housing.

\section{I}

The Problem-Substandard Housing and the Poor

There are approximately 35 million poor persons in the nation. ${ }^{2}$ Generally, they are not organized politically, economically, or socially. If employed, they are found most often in jobs without the protection and benefit of union organization or minimum wage law. Lower income and poor families tend to have more children than other income groups. This boosts their family needs beyond their capabilities and pyramids their problems. Due to their economic isolation or segregation from the mainstream of American "know-how" culture, they are not aware of scientific achievements and the available methods of family planning and birth control. Culturally segregated in the crowded city or culturally isolated in the rural areas, there is little opportunity for the poor to be part of, or proud of, the accomplishments of this country in any field of endeavor. Until recently the dialogue between the poor and the rest of the population of the nation has been practically nonexistent. Tom Sawyer and Huckleberry Finn for the new generation of Americans are dead. The Prince and the Pauper do not speak the same language. The lack of communication and understanding between the two groups is analogous to the situation existing in France prior to the French Revolution. The average suburbanite making his way between his home "styled for gracious living" and his job in the city rarely sees the poor and is as unconcerned as the members of the court of Louis XVI making their trips between Versailles and the fashionable shops of Paris. The saving grace and moral difference between the times is the aroused concern of the educational,

*A.B. x946, LL.B. 194x, University of Texas. Chief Counsel, Cooperative and Special Programs Section, Office of the General Counsel, Federal Housing Administration, Department of Housing and Urban Development.

The ideas and views expressed in this article are those of the author and do not represent the views and policy of the Federal Housing Administration or the Department of Housing and Urban Development.

${ }^{2}$ Hearings on the Federal Role in Urban Affairs Before the Subcomm. on Executive Reorganization of the Senate Comm. on Government Operations, 8gth Cong., 2d Sess., pt. I, at I47 (1966) [hereinafter cited as 1966 Hearings].

2See, e.g., 1966 Hearings, pt. 2, at 460; M. Harrington, The Other America i82 (I962). 
social, religious, business, labor, and political leaders of the nation with the problems of the poor. Enlightened leaders are aware that riots and violence against property are the harvest of generations of neglect and that the resources of a nation are dependent upon the productivity and cultural ties of its people.

In order to eliminate substandard housing, the nation would have to invest over $\$ 30$ billion. $^{3}$ It has been suggested that the rapidity of the implementation of a housing program of such magnitude is dependent upon economic conditions and that during inflationary periods the effectiveness of a subsidized housing program for the poor, due to rising costs, would be diminished. Conversely, when there is slack in the economy, the tempo of such a housing program could be accelerated with gains and benefits not only to the reduction of substandard housing but to the increase in economic activity in the nation. ${ }^{4}$ While this is economic theory, ironically it is not applied to the interstate highway construction program for which, as a people, we are spending $\$ 30$ billion at a rate of $\$ 4.4$ billion per year in federal grants, nor to the space program costing over $\$ 5$ billion a year. 5 The crisis of the poor cannot be treated solely with words and phrases. Treatment will require reallocation of dollars, employment and use of skilled technicians, and the elimination of political obstacles. In the dialogue relating to the needs of the nation, housing and other human necessities deserve first class priority.

\section{II}

\section{A Solution-Cooperative Self-Help Housing}

It is apparent that the cost of a subsidized housing program for the poor can be reduced by the value of self-help labor contributed by the future owners or occupants and that at any given time in the economy the use of self-help would result in more housing being built at reduced costs. A program involving self-help can be persuasive politically and can achieve many moral objectives.

The following short-run priorities ${ }^{6}$ would result in maximum immediate benefits to the poor:

(I) Through planned parenthood, help the poor control the size of their families. This objective can be achieved at a negligible cost to the nation and would, of course, in the long run be of great assistance in achieving the other priorities.

(2) Expand assistance to poor children and create jobs for their parents.

(3) Create subsidized standard housing for the working poor.

\footnotetext{
${ }^{3}$ S. Levitan, Programs in Aid of the Poor 57 (1965). (This work also appears as exhibit 42 of 1966 Hearings, pt. 2, at 459.)

II.

${ }^{5}$ II3 CoNG. Rec. H4799 (daily ed. April 27, 1967) (I967 National Housing Conference Legislative Resolutions, introduced for the RECORD by Congressman Patman).

- See S. Levitan, supra note 3, at 49-58.
} 
It is significant that each of the above short-run priorities contains elements of self-help which can be a part of, and furthered by, an effective self-help housing program.

\section{A. The Need for Organization}

In order for any area or locality to have an effective self-help housing program for the poor, there must be either a private or a public self-help housing organization which has a profound belief in self-help and which is able to provide the proper administration and support to the self-help housing specialialists who will select and work with the families who are to provide the labor.

In any given community the self-help housing sponsor would have to deal with the following principal preconstruction problems:

(I) Obtaining a working arrangement with the affected labor unions so that self-help labor by the prospective occupants will be accepted by the unions and will not be a cause for labor difficulties and delays during the construction period;

(2) Selecting and obtaining a site in the community for the new construction or the rehabilitation of existing housing;

(3) Selecting the construction foreman, the group social worker, and any other self-help specialists who may be needed for the project;

(4) Establishing criteria for the selection of self-help families, including a determination of the type, amount, and scheduling of self-help;

(5) Arranging for preparation of building or rehabilitation plans;

(6) Obtaining financing for the project; and

(7) Organizing and staffing the self-help cooperative or condominium assocition pending the transfer of memberships or title to the self-help families.

\section{B. Cooperative and Condominium Ownership}

In urban areas-city or suburb-the cooperative and condominium forms of ownership are particularly well-designed to further the aims of a self-help housing program, which include the development of individual self-esteem and pride inherent in home ownership as well as creating group and community spirit. These two forms of ownership are also adaptable and can be used in the development of detached, semi-detached, and row housing, as well as high-rise.

Under the cooperative form of ownership, a corporation owns the housing and each member owns stock in the corporation which entitles him to live in a unit after the execution of an occupancy agreement. One mortgage covers the entire project, and the members pay carrying charges under their occupancy agreements to the corporation. The corporation is responsible for all of the expenses of the project including taxes and mortgage payments. Each member occupant has an equal vote 
in electing the board of directors, but the carrying charges are established generally on the basis of unit size.

Under condominium ownership, fee simple title to a dwelling unit as well as specified undivided interest in the common areas and facilities is vested in each condominium owner. Each unit and its specified undivided interest are covered by a mortgage. Mortgage payments and taxes for the unit and its undivided interest are the responsibility of the individual unit owner. All of the units and their undivided interests are subject to a recorded plan of condominium ownership which restricts the use of the property and provides for the creation of an association of owners, consisting of all of the unit owners, which has through its board of directors the authority to assess each of the units for its share of the expenses relating to the common expenses of the association. The assessments as well as the voting rights in the association are established as a percentage of the value of the dwelling unit to the entire project.

Both cooperative and condominium ownership may include commercial as well as community facilities, and the leasing and use of same would be the responsibility of the board of directors of the cooperative or of the condominium. Both forms of ownership provide incentive to the owners and ample opportunity for them to develop personal and group abilities through cooperative and democratic processes. When combined with a self-help program, the participants would acquire technical knowledge and skills resulting in the creation of pride in the individual and the family through a feeling that they have learned something, perfected something, created something through their own abilities working with representatives of society who are interested in entering into a relationship with them for the development of their environment.

Legally, if desired, the cooperative and condominum forms of ownership are useful devices to restrict resale of the units to specified income groups. Such restrictions on resale could be included in the cooperative charter or by-laws, or in the condominium plan of ownership. Consequently, a self-help housing program using the cooperative or condominium form of ownership, which is subsidized either by public or private means, has a ready answer to any opposition or criticism that the housing could be acquired for speculative purposes.

If the self-help housing organization is properly based in the community, the cooperative and condominium forms of ownership would also permit the construction and use of any commercial and community facilities associated with the development on a cooperative basis. For example, with respect to commercial facilities, the housing cooperative could lease them to cooperative business ventures-groceries, drug stores, cafeterias, bakeries. In addition to the rental income received by the cooperative housing corporation from the enterprises, the sponsoring self-help organization could, with the approval of the community authorities, initiate these 
cooperative businesses with the dual purpose of their being used as training institutions for the residents of the area, who would be given the first opportunity for employment training, as well as affording all area residents lower prices for the goods and services provided on a cooperative basis. In some instances, the self-help sponsoring organization might be able to initiate the leasing of space from the cooperative or condominium housing owner by the city for the purpose of installing public health sub-stations, branch libraries, employment offices, and nurseries, thereby affording income to the housing cooperative or condominium, achieving the availability of public services to all residents of the area, and if an arrangement is made with the community, providing an opportunity and a place for training and employment of the low income people of the area in these particular fields. Whenever such cooperative or condominium housing for the poor can be located near other income group housing, both will reap benefits. For example, the middle or higher income housing occupants can be a source of employment for the residents of the low income project, who can carry forward cooperative principles they have learned by forming a cooperatively-operated enterprise to furnish domestic and similar services. Likewise, in a community development area where the sponsoring self-help organization can encourage the inclusion of special type housing such as nursing homes, hospitals, and elderly housing, the sponsor can increase its effectiveness by working out an employment training program which will provide jobs for the low income residents of the area and also provide the institutions with much needed services from a readily available labor source.

\section{Individual Participation}

Where self-help is used to build cooperative and condominium housing, the sponsoring agency should have an agreement with each self-help participant as to the type and amount of self-help labor required. The agreement should specifically provide that membership in the cooperative or title to the condominium unit will not be transferred to the participant until the required amount of labor has been completed. Such agreement may also provide for the transfer of the participant's rights to another self-help family which is willing and able to complete the self-help contract in the event the original participant is unable to complete. Prior to the commencement of construction and the execution of the self-help contracts, there should be sufficient meetings with the self-help families, the social worker, and the construction foreman so that each participant and his family will know exactly what will be expected of them. The final selection of families to be involved should come after these explanatory meetings. It is recommended for cooperative and condominium housing that teams of workers will be formed and that work will be carried out on a project construction basis rather than on an individual home basis. When the project is completed, each family will draw lots for the particular type and size of unit for which it is eligible. 
There are several advantages in utilizing a team system for working on all of the houses rather than each individual family working exclusively on its own house. The construction foreman can teach the unskilled participants on a group basis and does not have to separately instruct each family. As the group progresses from house to house, the foreman will not have to supervise as closely since the repetition of the same scheduled work on each house will increase the skill of the team's performance, and as a result, the foreman can devote his time to a new team which will be scheduled to perform another stage of construction. Team building also encourages exchange of ideas within the group and offers an opportunity to learn from each other's abilities and errors. Finally, there is no temptation to give more effort and skill to any one house since no particular house has been assigned to any participant during construction.

\section{Financing}

Section 212 of the National Housing Act, with certain exceptions, provides that in all FHA multifamily housing projects prevailing wages established by the Department of Labor must be paid. ${ }^{7}$ Accordingly, unless this section is amended, prevailing wages must be paid to laborers building any section $213^{8}$ cooperative or any section $234^{9}$ condominium project; and self-help or donated labor by low income families would not be possible. However, this requirement for prevailing wages would not apply to self-help or donated labor in a section $221(d)(3)^{10}$ low and moderate income cooperative project where members of the cooperative are not otherwise employed in the construction of the project and voluntarily donate their services without compensation. Therefore, the principles of self-help and donated labor are available to cooperatives for low income groups under section $22 \mathrm{r}$ (d) (3).

Assuming that the restrictions imposed by prevailing wages under the National Housing Act can be relaxed, the FHA mortgage insurance programs for sections 213 cooperatives and section 234 condominiums could serve as financing vehicles for a self-help housing program. However, in order to reach low income groups, even with the use of self-help equity, it may be necessary for some form of subsidy to be available. There could be, for example, a combination of a FHA-insured mortgage covering the project at market rate interest and a grant, either from public or private sources. The grant would permit the FHA-insured mortgage to be in a lower amount with resulting lower monthly payments by the low income cooperator or condominium unit owner. This procedure would parallel one used now by FHA and the Department of Health, Education, and Welfare involving nonprofit nursing homes which are financed by a combination of a Hill-Burton federal grant and a

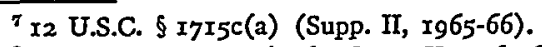

8 I2 U.S.C. \$ r715e (1964, Supp. II, 1965-66).

I2 U.S.C. $\$$ I715y (1964, Supp. II, 1965-66).

${ }^{10} 12$ U.S.C. $\$$ I $_{75} l$ (Supp. II, I965-66).
} 
FHA-insured mortgage. Forms of subsidy, such as low interest rates, for condomium individual mortgages would require legislative changes to the National Housing Act.

Great strides have been made in housing the middle income group. In the heat of political debate or in the meticulous listing of his mortgage interest on his income tax return, the typical middle or upper income home owner would look askance at any person who might suggest that he is enjoying the benefit of a federal subsidy by reason of the interest deduction in determining the amount of his income tax. It has been estimated that in I962, federal subsidies by reason of interest tax deductions to homeowners in the upper twenty per cent of income distribution amounted to $\$$ r.7 billion as compared to $\$ 820$ million of federal subsidies for poor people. ${ }^{11}$

In view of the great shortage of standard housing for the low income group, new avenues of federal revenue may need exploration. In inflationary times, when the government has so many top priorities-foreign and domestic-there may be some economic merit in suggesting that expenditures for luxury housing result in the channeling of goods and services away from housing for the low income group. The analogy can be drawn that taxes on nonessentials, such as furs, perfumes, and other luxury items, may be extended in the form of a federal transfer tax to luxury homes and apartments. The objective of the tax would be not only to produce revenue but also to direct goods, services, and money to housing for which there is a greater need. Since such a tax would fall primarily on the upper income group rather than on the middle income group, it might receive the support of the majority of the people. Alternatively, the amount of deductible mortgage interest for income tax purposes could be limited as in the case of charitable contributions and medical expenses, thereby increasing federal income tax revenue. The limitation on deductible mortgage interest could be set at a figure which would generally not affect the middle income home or apartment owners.

\section{Conclusion}

The use of self-help in the construction of cooperative and condominium housing should be explored as one of the methods of achieving home ownership for the low income group in the United States. Self-help has been successfully used in undeveloped countries ${ }^{12}$ and is receiving additional interest in the United States. ${ }^{13}$

\footnotetext{
${ }^{11}$ S. Levitsin, supro note 3 , at 40.

12 See Departaient of Economic and Soctal Affairs, United Nations, Manual on Self-Help Housing, U.N. Doc. ST/SOA/53 (I964); Inter-American Housing and Planning Center (Bogot $\delta$ ), Pan AMerican Union, Self-Herp Housino Guide ( 1962 ).

${ }^{13}$ See Ir3 Cong. REc. S3769 (daily ed. March ${ }_{34}$, 1967) (The War on Poverty-message from the President); 1966 Hearings, pt. I, at 38 (statement of Senator Robert Kennedy); 113 Cong. REc. Hg9 (daily ed. Jan. II, 1967) (remarks of Congressman Widnall concerning the Percy Home Ownership Plan); Blackburn, Citizen Participation, 20 J. Housing 440 ( $\left.\mathrm{x}_{9} 6_{3}\right)$, describing the Flanner Homes self-help project in Indianapolis.
} 